\title{
PERANCANGAN "LOGO-MOTIVE” Tanda Visual sebagai Sarana Memotivasi Masyarakat agar Membuang Sampah pada Tempatnya
}

\author{
Ahmad Syaiful Anwar ${ }^{1}$, Aster Stephanie ${ }^{2}$, Valdi Harris Hibatullah ${ }^{3}$, Bernardus \\ Andang Prasetya Adiwibawa ${ }^{4}$ \\ 1,2,3,4 Universitas Dian Nuswantoro, Semarang
}

Received: 09 Agustus 2017

Revised: 18 September 2017

Accepted: 9 Februari 2018

Available online at: bit.do/demandia

\begin{abstract}
Abstrak: Membuang sampah sembarangan masih menjadi kebiasaan buruk masyarakat di Indonesia. Masyarakat perlu terus selalu diberi dorongan untuk mengubah kebiasaan itu. Penelitian ini dilakukan sebagai dasar perancangan suatu tanda visual yang dapat digunakan untuk memotivasi masyarakat agar membuang sampah pada tempatnya. Penelitian ini menggunakan pendekatan kualitatif dan kuantitatif. Data diperoleh melalui survey dan observasi lapangan. Tanda visual hasil perancangan ini diberi nama LOGOMOTIVE, yang dapat ditempatkan pada berbagai media. LOGO-MOTIVE dalam hal ini hanya sekedar nama untuk tanda visual atau ikon yang digunakan untuk memotivasi orang-orang.
\end{abstract}

Kata kunci: membuang sampah, motivasi, desain, logo-motive

Abstract: Littering is still being bad habit of Indonesian society. People need to be constantly encouraged to change it. This research is conducted as the basis of visual sign design that can be used to motivate people to dispose of garbage in its place. This research uses qualitative and quantitative approach. Data obtained through survey and field observation. The name of design result of the visual sign is LOGO-MOTIVE, that can be placed on various media. LOGO-MOTIVE in this case is just a NAME for the visual marks or icons used to motivate people.

Keywords: littering, motivation, design, logo-motive

Penulis adalah mahasiswa program studi Desain Komunikasi Visual yang mengikuti Program Kreatif Mahasiswa (PKM) Bidang Penelitian Humaniora, dan dosen pembimbing PKM program studi Desain Komunikasi Visual di Universitas Dian Nuswantoro, Semarang (e-mail: asyaifulanwar97@gmail.com, astersteph69@gmail.com, valdihibatullah@gmail.com, andangprast@dsn.dinus.ac.id). 


\section{PENDAHULUAN}

Membuang sampah sembarangan masih menjadi salah satu penyakit yang masih melekat dalam masyarakat Indonesia. Hal itu dapat mengakibatkan dampak buruk ke lingkungan, seperti banjir yang terjadi di Pekanbaru pada Juni lalu (Syukur, 2017). Kasus lain juga terjadi di Kota Bogor, banjir karena hujan deras (Sudarno, 2017). Salah satu penyebabnya yaitu membuang sampah sembarangan. Ini juga ditegaskan oleh salah satu pejabat pemerintah, Jumatni, yang menyatakan bahwa kesadaran untuk membuang sampah pada tempatnya masih minim, pada gilirannya dapat mengakibatkan banjir dan menimbulkan penyakit. (Ronny, 2014).

Beberapa tindakan yang dilakukan pemerintah untuk mengatasi masalah ini antara lain melalui penyuluhan, penempelan poster-poster di tempat-tempat publik, dan pemasangan rambu-rambu larangan membuang sampah. Undangundang dan peraturan pemerintah yang ada belum dijalankan dengan baik. Partisipasi masyarakat dalam membuang sampah juga masih kurang.

Partisipasi masyarakat sesungguhnya diberi ruang bahkan dimandatkan dalam undang-undang. Dalam UU No.18 Tahun 2008 tentang Pengelolaan Sampah, pasal 14 dijelaskan bahwa "Setiap produsen harus mencantumkan label atau tanda yang berhubungan dengan pengurangan dan penanganan sampah pada kemasan dan/atau produknya". Sedangkan pada pasal 15 dijelaskan bahwa "Produsen wajib mengelola kemasan dan/atau barang yang diproduksinya yang tidak dapat atau sulit terurai oleh proses alam". Dari dua pasal dapat disimpulkan bahwa produsen juga memiliki peran sebagai motivator masyarakat untuk membuang sampah pada tempatnya.

Berkait dengan aturan hukum semacam itu dan kondisi dimana fenomena membuang sampah yang tidak benar masih terjadi, maka pemerintah dan produsen perlu terus memberikan dorongan atau motivasi. Metode pemberian 
motivasi kepada masyarakat itu dapat dilakukan dalam berbagai bentuk, salah satu model atau bentuk untuk itu adalah berupa suatu tanda visual yang dapat ditempatkan ke berbagai media.

Penelitian ini berangkat dari keprihatinan penulis bahwa masih banyak sampah berceceran di ruang publik, terutama pasar, toko-toko retail dan sekolahsekolah. Padahal ada peraturan untuk mendorong produsen terlibat dalam memotivasi masyarakat. Dari fenomena ini muncul ide bagaimana jika diciptakan suatu tanda visual yang dapat digunakan untuk memotivasi. Tanda visual yang dirancang itu diberi Ikon tersebut diberi nama LOGO-MOTIVE, dalam hal ini hanya sekedar nama untuk tanda visual atau ikon yang digunakan. Nama tersebut muncul dari permainan kata "lokomotive" dan berhubungan dengan logo sebagai salah satu bentuk tanda visual. Permainan kata itu kemudian berarti logo, tanda visual, yang digunakan untuk memotivasi.

\section{KAJIAN TEORI}

Motivasi, menurut Herpen, dkk. (2002) dapat diartikan sebagai kekuatan (energi) seseorang yang dapat menimbulkan tingkat persistensi dan entusiasmenya dalam melaksanakan suatu kegiatan. Ada dua kategori motivasi menurutnya, yaitu; motivasi intrinsik yang bersumber dari dalam diri individu itu sendiri dan motivasi ekstrinsik dari luar individu.

Suwatno dan Priansa (2011) dalam membahas beberapa teori motivasi, menyebutkan bahwa salah satunya adalah Teori Kaitan Imbalan dengan Prestasi. Menurut teori ini, motivasi seseorang dipengaruhi berbagai faktor, baik internal maupun eksternal. Faktor internal adalah bagaimana seseorang menilai diri sendiri, gengsi, harapan pribadi, kebutuhaan, keinginan, kepuasan kerja, prestasi kerja yang dihasilkan. Sementara faktor eksternal, bergubungan antara lain dengan: profesi dan mata pencaharian, pier-group, lembaga atau organisasi 
tempat bekerja, situasi lingkungan pada umumnya, sistem imbalan yang berlaku dan cara penerapannya. Pentingnya mengetahui faktor-faktor mempengaruhi motivasi dalam diri seseorang dapat dijadikan sebagai acuan untuk mengubah perilaku suatu individu.

Pengalaman, pendidikan, preferensi, dan lingkungan sosial mempengaruhi individu untuk memberi makna yang berbeda-beda terhadap suatu simbol. Ketika individu menafsirkan simbol, maka akan diserap ke dalam kesadaran dan memaknainya secara subjektif. Meminjam konsepsi Lee dan Johnson (2004) pemahaman kebudayaan masyarakat merupakan kebutuhan utama dalam kegiatan kampanye. Masyarakat masih mempunyai kebudayaan membuang sampah sembarangan. Oleh karena itu, perlunya mengetahui alasan masyarakat melakukan tindakan tersebut sehingga dapat ditemukan faktor-faktor apa saja yang dapat memotivasi mereka.

Faktor-faktor ini yang kemudian digunakan untuk merancang sebuah sarana informasi dan intruksi. Menurut Cenadi (2004), Desain Komunikasi Visual dapat digunakan sebagai sarana informasi dan instruksi. Dengan demikian berbagai bentuk visual, diantaranya ikon, lambang, maskot atau tanda, yang bertujuan memberikan informasi dan intruksi untuk membuang sampah pada tempatnya sehingga dapat digunakan sebagai sarana kampanye.

\section{METODE PENELITIAN}

Metode penelitian yang digunakan sebagai dasar perancangan utamanya menggunakan pendekatan kualitatif. Dukungan data kuantitatif digunakan untuk menjelaskan hal-hal yang dersifat numerik. Data dikumpulkan melalui observasi dan wawancara. Jenis data yang dikumpulkan antara lain data kualitatif dalam bentuk pendapat, testimoni dan deskripsi atas observasi, dan data kuantitatif dalam bentuk tabulasi angka-angka. 


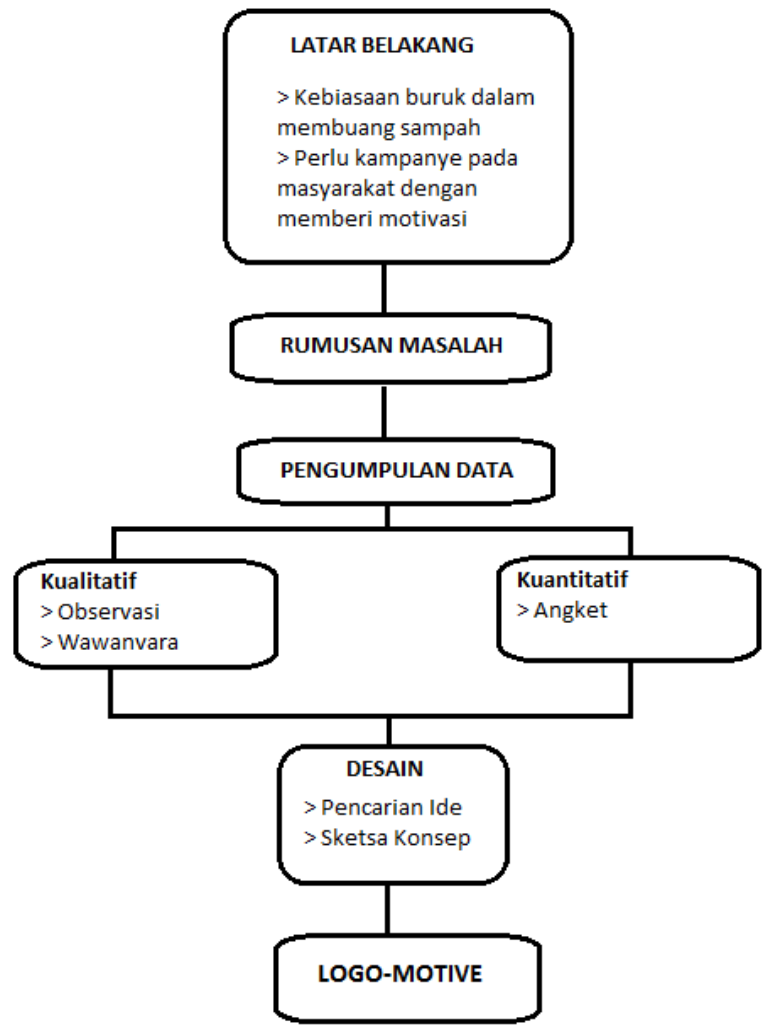

Skema 1 Alur Metode Penelitian

Sumber : Anwar, Stephanie, Hibatullah, dan Adiwibawa : 2017

Observasi dilakukan di tempat-tempat publik di Semarang. Tempat publik yang diobservasi dikelompokkan dalam tiga tempat, yaitu retail modern, pasar traditional, dan sekolah. Subyek penelitian adalah pengunjung tempat publik di masing-masing kategori tempat di Semarang pada hari Sabtu, Minggu dan Senin dengan fokus pada perilaku mereka membuang sampah. Penentuan jumlah tempat dalam masing-masing kategori tersebut dihitung secara proporsional berdasar jumlah populasi di kecamatan di Kota Semarang. Dari 16 kecamatan yang ada, difokuskan pada 5 kecamatan di pusat Kota Semarang. Jumlah tempat dalam masing-masing kategori dengan demikian adalah Retail Modern 10 tempat, Pasar Tradisional 3 tempat dan Sekolah Menengah Atas (SMU/ SMK) 5 tempat. 
Wawancara dilakukan kepada pelaku pembuang sampah sembarangan dan pelaku pembuang sampah pada tempatnya. Setiap tempat akan diambil 2-4 responden secara acak. Beberapa pertanyaan untuk menggali dasar perilaku antara lain; (1) alasan membuang sampah, (2) respon moral setelah membuang sampah, (3) preferensi ideal tentang lingkungan bersih, (4) motivasi perilaku positif membuang sampah pada tempatnya dan (5) kebutuhan akan tanda/ bentuk visual untuk memotivasi

Dukungan data kuantitatif untuk melengkapi analisis deskripsi ini diperoleh dari tabulasi data hasil observasi yang meliputi jenis dan prosentase sampah yang dibuang, bentuk kemasan produk dan prosentase buangan menurut produk dan kemasannya.

\section{HASIL DAN DISKUSI}

Selama observasi di 10 retail modern yang tersebar di 5 kecamatan Kota Semarang, ditemukan yang membuang sampah sembarangan lebih banyak daripada yang membuang sampah pada tempatnya. Selama tiga jam berada di retail modern tersebut, ditemukan 70 dari 107 tidak membuang sampah pada tempatnya. Dari 25 dari 70 orang tersebut diwawancara mengenai variabelvariabel pertanyaan. Banyak dari responden mengatakan bahwa alasan tidak membuang sampah pada tempatnya adalah ada petugas kebersihan, terburuburu, lupa, dan letak tempat sampah yang jauh. Respon moral dari 25 responden tersebut adalah timbul perasaan malu dan merasa bersalah, namun beberapa responden ada yang menyatakan merasa biasa saja. Lalu ketika ditanyakan tentang apa yang bisa memotivasi, responden menjawab bahwa ada peringatan yang jelas dan ada tempat sampah yang terlihat dengan jelas. Beberapa menjawab jika ada yang menegur mereka. 25 responden ketika ditanyai apakah perlu adanya tanda peringatan, 21 orang mengatakan perlu. Beberapa orang yang mengatakan 
tidak perlu beralasan bahwa itu kesadaran diri sendiri jadi tidak perlu ada tanda peringatan. Berdasarkan wawancara tersebut dapat disimpulkan bahwa pengunjung retail modern masih bisa didorong untuk membuang sampah pada tempatnya karena masih punya perasaan bersalah saat membuang sampah sembarangan dan membutuhkan suatu penanda yang jelas.

Pada observasi di pasar, terdapat petugas kebersihan yang bertugas setiap sehari satu kali hal ini membuat pedagang pedagang pasar kurang peduli dengan lingkungan sekitar. Pedagang pasar juga tidak peduli dengan kebersihan kios setiap waktu, kios hanya dibersihkan saat buka dan tutup. Empat pemilik kios yang tidak menjaga kebersihan kios mereka diwawancarai. Mereka menjawab bahwa mereka biasa saja dengan dengan lingkungan kotor bahkan ada yang menegaskan bahwa pasar itu tempatnya sampah jadi tidak perlu diberi tanda atau harus dijaga kebersihannya. Beberapa pedagang juga menyatakan bahwa ada petugas kebersihan sehingga mereka mengatakan tidak perlu bersih-bersih kecuali jika ada waktu luang atau kios akan ditutup. Berdasarkan wawancara tersebut, disimpulkan bahwa di pasar sulit diberi tanda atau tempat sampah karena mayoritas pedagang mengandalkan petugas kebersihan dan hanya memperhatikan kebersihan ketika tidak ada pembeli.

Untuk benda-benda yang dibuang ke tempat dari seluruh tempat observasi, kami kalkulasikan dalam tabel dibawah ini :

Tabel 1. Jumlah dan jenis sampah yang dibuang ke tempat sampah.

\begin{tabular}{|c|c|c|}
\hline No & Jenis Sampah & Jumlah (\%) \\
\hline 1 & Tabung Karton & 1,74 \\
\hline 2 & Cup Karton & 2,99 \\
\hline 3 & Kantong Plastik & 17,41 \\
\hline 4 & Kertas & 10,45 \\
\hline
\end{tabular}




\begin{tabular}{clc}
\hline 5 & Botol Plastik & 22,14 \\
\hline 6 & Cup Plastik & 8,46 \\
\hline 7 & Botol Kaca & 1,24 \\
\hline 8 & Tabung Plastik & 1,00 \\
\hline 9 & Tabung Kaleng & 4,48 \\
\hline 10 & Kotak Plastik & 5,47 \\
\hline 11 & Kotak Stereoform & 1,24 \\
\hline 12 & Plastik Plastis & 11,69 \\
\hline 13 & Kotak Karton & 3,48 \\
\hline 14 & Kayu Plastis & 1,74 \\
\hline 16 & Stereoform Lembaran & 0,75 \\
\hline & & Total (\%) \\
\hline
\end{tabular}

Sumber: Anwar, Stephanie, Hibatullah, dan Adiwibawa : 2017

Berdasarkan data diatas disimpulkan variabel-variabel yang akan menentukan desain LOGO-MOTIVE yang dapat memotivasi masyarakat membuang sampah pada tempatnya. Variabel-variabel tersebut adalah sebagai berikut : pertama, sasaran komunikasi adalah semua kalangan yang berusia 15 30 th. Hal ini berdasarkan pada saat wawancara orang berusia diatas 30 tahun menolak mengubah kebiasaannya,

Kedua, desain tanda visual dapat diimplementasikan ke tempat sampah dan kemasan (terutama kantong plastik dan botol plastik). Ini disimpulkan dari sampah terbanyak yang ditemukan selama penelitian. Desain juga harus bisa diimplementasikan ke sign system karena dari wawancara orang - orang masih membutuhkan sign system.

Ketiga, bentuk tanda visual dapat menimbulkan perasaan bersalah ketika membuang sampah pada sembarangan, dan juga memuat unsur teguran kepada 
pembuang sampah sembarangan. Keempat, bentuk tanda visual harus eyecatching, dapat dilihat dari jauh, dan menarik perhatian target audience.

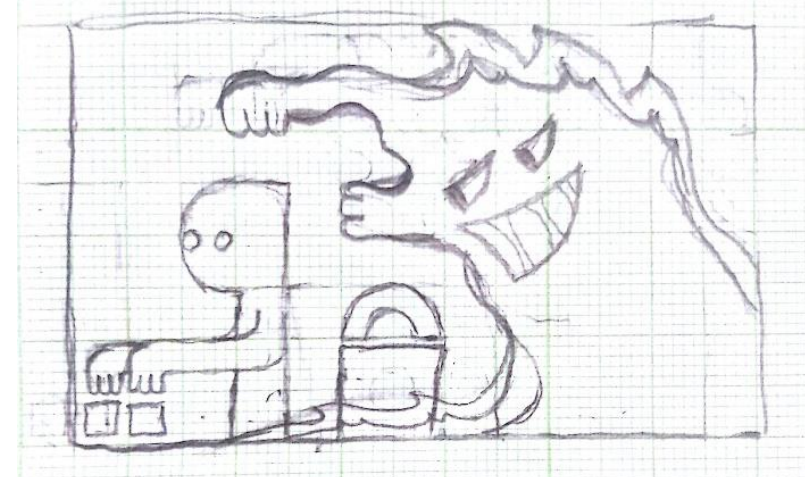

Gambar 1. Sketsa Desain

Sumber: Anwar, Stephanie, Hibatullah, dan Adiwibawa : 2017
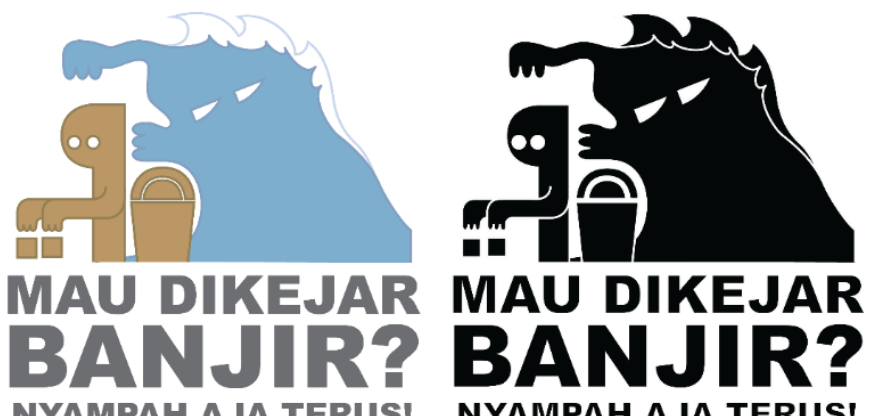

MAU DIKEJAR

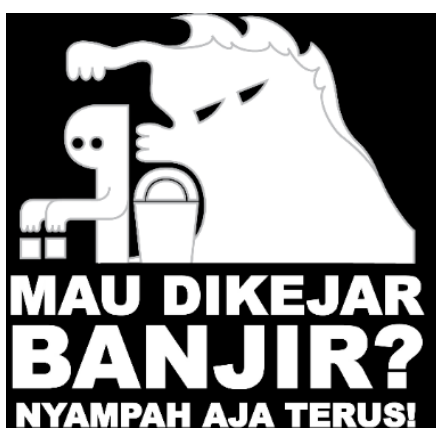

Gambar 2. Design dan Alternatifnya

Sumber: Anwar, Stephanie, Hibatullah, dan Adiwibawa : 2017

\section{Konsep Desain}

\section{a. Konsep visual}

Visualisasi ikon menggunakan ilustrasi terdiri dari objek manusia, sampah, tempat sampah, dan air. Objek manusia mewakili masyarakat yang membuang sampah tidak pada tempatnya, ditandai dengan objek manusia yang membuang 
sampah namun arahnya berlawanan dari arah tempat sampah. Air mewakili banjir yang akan meneror manusia yang tidak membuang sampah pada tempatnya.

Konsep ini berupa pengingat yang berupa ancaman, bahwasanya membuang sampah tidak pada tempatnya dapat menimbulkan banyak sekali dampak buruk.

\section{b. Konsep Copywriting}

Konsep komunikasi pada logo ini berupa sebuah ancaman sekaligus sindiran kepada masyarakat yang masih belum sadar akan bahayanya membuang sampah tidak pada tempatnya. Ancaman yang dimaksud terletak pada kalimat "mau dikejar banjir?", sedangkan sindirannya adalah "nyampah aja terus!". Kalimat yang digunakan pada logo ini tergolong kalimat tidak baku, dan merupakan contoh kalimat yang biasa digunakan sehari-hari oleh masyarakat dan memiliki sifat yang intim dipikiran dan ingatan masyarakat, sehingga seolah-olah berupa teguran langsung oleh orang-orang yang dekat dengan masyarakat yang masih belum sadar akan bahayanya membuang sampah tidak pada tempatnya.

Konsep berupa ancaman dan sindiran ini berdasarkan hasil wawancara beberapa responden merasa tersindir dan malu saat ditanya alasan mengapa membuang sampah sembarangan. Selain itu masyarakat sudah tidak perhatian dengan konsep copywriting yang berupa imbauan baku dan halus seperti "jagalah kebersihan lingkungan", "kebersihan adalah sebagian dari iman", "buanglah sampah pada tempatnya", ataupun "jangan buang sampah di sini".

\section{c. Penerapan}

Pada kantong plastik, logo-motive dijadikan sebagai pola dasar, dengan ukuran minimal $40 \mathrm{~mm} \times 40 \mathrm{~mm}$ dan maksimal $50 \mathrm{~mm} \times 50 \mathrm{~mm}$. Pengaturan warna disesuaikan, dapat berupa warna putih, hitam, ataupun warna asli logo-motive. 


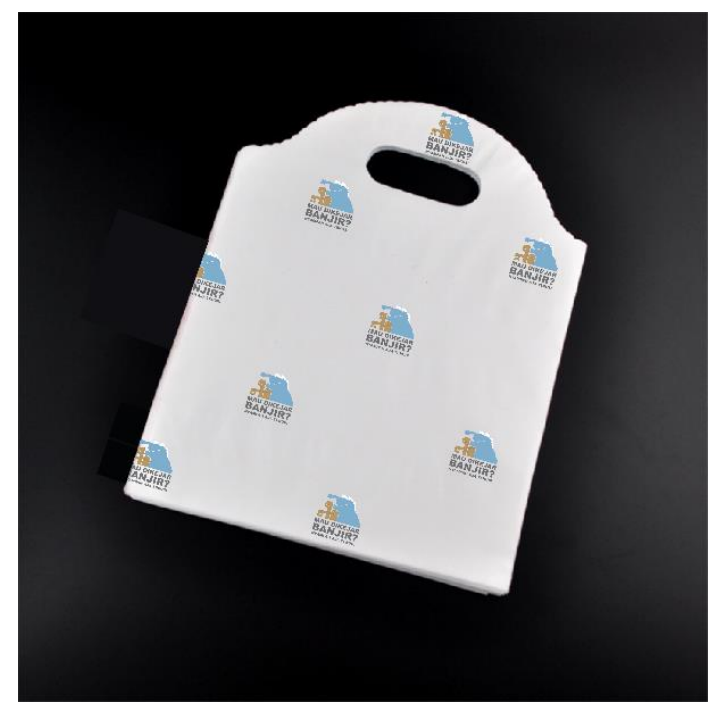

Gambar 3. Aplikasi pada kantong plastik

Sumber: Anwar, Stephanie, Hibatullah, dan Adiwibawa : 2017

Pada kemasan, logo-motive diletakkan bersanding dengan logo-logo sponsor, perusahan, atau sertifikasi, dengan ukuran minimal $5 \mathrm{~mm} \times 5 \mathrm{~mm}$ dan maksimal $10 \mathrm{~mm} \times 10 \mathrm{~mm}$. Pengaturan warna disesuaikan, dapat berupa warna putih, hitam, ataupun warna asli logo-motive.

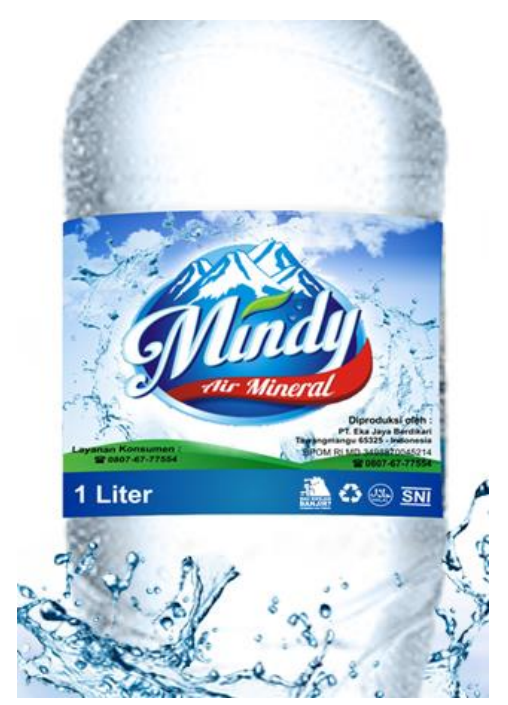

Gambar 4. Aplikasi pada kemasan air mineral Sumber: Anwar, Stephanie, Hibatullah, dan Adiwibawa : 2017 
Pada tempat sampah yang memiliki sisi poligonal, logo-motive diletakkan pada setiap sisi tempat sampah. Sedangkan pada tempat sampah berbentuk tabung, logomotive diletakkan pada setiap sisi yang menghadap 4 penjuru mata angin, yaitu utara, timur, selatan, dan barat. Ukuran logo-motive pada semua jenis tempat sampah adalah minimal $200 \mathrm{~mm} \times 200 \mathrm{~mm}$ dan maksimal adalah $500 \mathrm{~mm} \times$ $500 \mathrm{~mm}$.

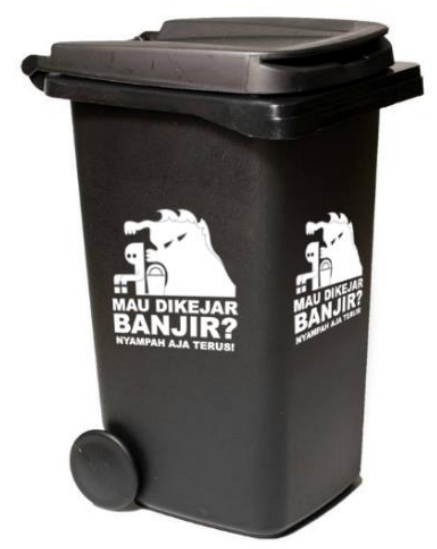

Gambar 5. Aplikasi pada tempat sampah Sumber: Anwar, Stephanie, Hibatullah, dan Adiwibawa : 2017

\section{KESIMPULAN}

Untuk membentuk suatu kebiasaan, seseorang dapat diberikan motivasi. Motivasi dapat bisa bersumber dari luar individu. Sumber motivasi dari luar individu tidak hanya berupa sebuah ujaran atau tertulis namun juga dapat diwujudkan dalam bentuk visual. Dengan melakukan pengamatan terhadap kebiasaan masyarakat maka ditemukan faktor-faktor apa saja yang bisa memotivasi perilaku masyarakat menjadi lebih baik kemudian dari faktor-faktor itu dapat diwujudkan ke dalam bentuk visual. 
Perlunya memahami perilaku target audiens sebelum merancang sebuah desain sangat penting. Setelah penelitian ini dilakukan, tidak semua kalangan masyarakat ingin mengubah kebiasaannya. Beberapa dari responden ternyata tidak mempunyai keinginan untuk mengubah kebiasaannya. Oleh karena itu perancangan desain ikon ini dibatasi untuk usia 15 - 30 tahun.

\section{PERNYATAAN PENGHARGAAN}

Penulis mengucapkan terima kasih kepada DITJEN DIKTI atas dana hibah PKM-Penelitian. Ucapan terima kasih kepada Khamadi, M Ds. Yang membantu penulisan jurnal, Erika Devi Udayanti, S Kom., M Cs. dan staff-staff Biro Kemahasiswaan Universitas Dian Nuswantoro yang mengawasi dan membimbing proses penelitian kami, Dinas Pendidikan dan Kebudayaan serta Kepala Sekolah yang mengijinkan kami riset di SMA Krista Mitra.

\section{DAFTAR PUSTAKA}

Cenadi, C. S. 2004. Elemen-elemen dalam Desain Komunikasi Visual. Jurnal Nirmana Vol 1 No 1. Universitas Petra Surabaya.

Herpen, Marco; Praag, Mirjan and Cools, Kees. 2002. The Effects of Performance Measurement and Compensation on Motivation and Emperical Study. Conference of The Performance Measurement Association in Boston pp. $1-34$

Lee, Monle dan Johnson, Carla, 2004. Prinsip-prinsip pokok periklanan dalam perspektif global. Diterjemahkan oleh Haris Munandar dan Dudy Priatna. Edisi 1. Jakarta: Prenada.

Ronny, NT. (2014, 30 Agustus). DPRD Imbau Masyarakat Jangan Buang Sampah Sembarangan. Antaranews (online), 1 halaman. Tersedia : 
http://kalteng.antaranews.com/berita/233316/dprd-imbau-masyarakatjangan-buang-sampah-sembarangan (diakses pada 17 Juli 2017)

Sudarno, Ahmad (2017,10 Juli). Hujan Deras Semalaman Ratusan Rumah di Bogor Terendam Banjir. Liputan 6 (online), 1 halaman. Tersedia :

http://news.liputan6.com/read/3017336/hujan-deras-semalamanratusan-rumah-di-bogor-terendam-banjir?source=search (diakses pada 11 Juli 2017)

Suwatno and Priansa, D.J. 2011. Manajemen SDM Dalam Organisasi Publik dan Bisnis. Bandung : Alfabeta.

Syukur, M. (2017,23 Juni). Banjir Jadi Kado Ulang Tahun Kota Pekanbaru. Liputan 6 (online), 1 halaman. Tersedia : http://regional.liputan6.com/read/3001752/banjir-jadi-kado-ulangtahun-kota-pekanbaru?source=search (diakses pada $11 \mathrm{Juli} 2017$ ) 